\title{
PAIN MANAGEMENT OF NEWBORN WITH EPIDERMOLYSIS BULLOSA FOR WOUND DRESSING: A CASE REPORT
}

\author{
Seyhan Balli Sevgi \\ Sehit Sait Erturk Government Hospital, Ankara, Turkey
}

Primljen/Received 03. 06. 2020. god.

Abstract: Epidermolysis bullosa (EB) is a genetic disease characterized by blisters on the skin and mucous membranes as a result of mechanical fragility. There are four types of EB: simplex (EBS), junctional (JEB), dystrophic forms (DEB), and Kindler syndrome. Simple analgesics such as paracetamol and ibuprofen in EB are also sufficient to reduce pain. Opioids and anxiolytics are necessary for severe pain during wound dressings. In this report, a case of JEB and its pain management at home during dressing by an anesthesist is presented.

Key words: Epidermolysis bullosa, chronic pain, home-care patients, wound dressing.

\section{INTRODUCTION}

Epidermolysis bullosa (EB) is a chronic, rare and heterogeneous group of diseases with blisters and erosions with minimal trauma in the deep and mucous membranes (1). EB has been classified into four categories according to the level of division in the dermal/epidermal compartment: EB simplex (EBS), junctional EB (JEB), dystrophic EB (DEB), and Kindler's syndrome (2).

Epidermolysis bullosa doesn't have a definitive treatment, but supportive treatment is applied. Cases should be protected from trauma, topical agent application should prevent infections and erosion, the skin should be moisturized, and infections must be treated. The most important goal during lesion treatment is to prevent pain during wound dressing; accordingly, atraumatic dressings should be applied (3). However, the availability of supplies and time required for patients, personal choice, and the carer's lifestyle also play important roles in preventing pain and bleeding (4). In this case report, we present the management of pain during wound dressings of patients with JEB at home in the neonatal period.Written consent was obtained from the patient's father for publication of this report.
Prihvaćen/Accepted 24. 07. 2020. god.

\section{CASE REPORT}

A 41-weeks-old girl who was born weighing 3300 $\mathrm{g}$ via the normal spontaneous vaginal route. During labor, there were no complications. Ten days after birth, the patient was diagnosed as having junctional epidermolysis bullosa in a tertiary hospital, which was widespread over her body, but especially on the hands, feet, and in the gluteal region. Twenty five days after birth, the home health care unit began applying the patient's dressings at the family's home.

In her physical examination, body weight, height, and head circumference were normal and vital findings were stable. Widespread bullous lesions were found in the mouth mucosa, occipital region, ear bones, on both hands, arms, legs and feet, and in the lumbar and gluteal region (Figures 1, 2, and 3).

The Neonatal Facial Coding Scale (NFCS) was used during dressing changes (Table 1). Despite sensitive and careful handling by an anesthetist, the NFCS score was 9 points during the first dressing and the procedure lasted 90 minutes. The baby was constantly crying during the whole process. Bandages were wrapped around the arms, legs, chest and back, and was fixed. Two-way tubular bandages were used to strengthen the

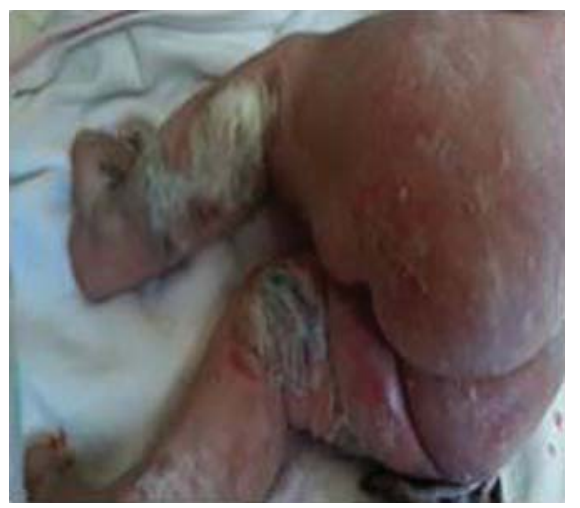

Figure 1. Appearance of lesions in patient with newborn epidermolysis bullosa 1 
Table 1. Neonatal Facial Coding Scale

\begin{tabular}{|c|c|c|c|c|c|c|}
\hline \multirow[t]{2}{*}{$\begin{array}{c}\text { Neonatal Facial Coding } \\
\text { Scale(NFCS) }\end{array}$} & \multicolumn{2}{|c|}{$\begin{array}{l}\text { 1st wound dressing } \\
\text { without using analgesics }\end{array}$} & \multicolumn{2}{|c|}{$\begin{array}{l}\text { 2nd wound dressing } \\
\text { (paracetamol) }\end{array}$} & \multicolumn{2}{|c|}{$\begin{array}{l}\text { 3rd wound dressing } \\
\text { (paracetamol, tramadol } \\
\text { and hydroxyzine } \\
\text { dihydrochloride) }\end{array}$} \\
\hline & 0 point & 1 point & 0 point & 1 point & 0 point & 1 point \\
\hline Brow bulge & & $\sqrt{ }$ & & $\sqrt{ }$ & & $\sqrt{ }$ \\
\hline Eye squeeze & & $\sqrt{ }$ & & $\sqrt{ }$ & & $\sqrt{ }$ \\
\hline Deepening of nasolabial furrow & & $\sqrt{ }$ & & $\sqrt{ }$ & $\sqrt{ }$ & \\
\hline Open lips & & $\sqrt{ }$ & & $\sqrt{ }$ & $\sqrt{ }$ & \\
\hline $\begin{array}{l}\text { Mouth stretch } \\
\text { (horizontal or vertical) }\end{array}$ & & $\sqrt{ }$ & & $\sqrt{ }$ & $\sqrt{ }$ & \\
\hline Lip shrink & & $\sqrt{ }$ & & $\sqrt{ }$ & $\sqrt{ }$ & \\
\hline Tongue tautening & & $\sqrt{ }$ & $\sqrt{ }$ & & $\sqrt{ }$ & \\
\hline Chin quiver & & $\sqrt{ }$ & $\sqrt{ }$ & & $\sqrt{ }$ & \\
\hline Tongue protrusion & & $\sqrt{ }$ & $\sqrt{ }$ & & $\sqrt{ }$ & \\
\hline TOTAL & & & & & & \\
\hline
\end{tabular}

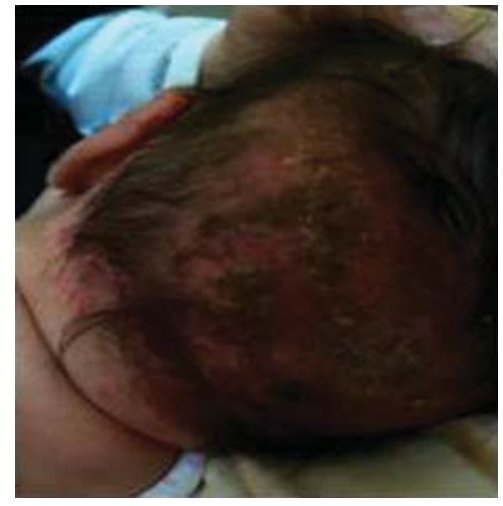

Figure 2. Appearance of lesions in patient with newborn epidermolysis bullosa 2

coil. After 3 days, the same wound care products were used for the reconstructed dressing. Six NFCS points were observed 1 hour after $15 \mathrm{mg} / \mathrm{kg}$ paracetamol oral administration and the dressing lasted for 45 minutes. The baby was crying only during the whole process. However, approximately 1 hour after the 2 nd wound dressing, the patient's dressings were removed by the family because she was crying severely. After half an hour, the redness decreased and the baby settled; there was widespread redness throughout the body and the wound care products were removed. Allergic response was considered. After 3 days, $15 \mathrm{mg} / \mathrm{kg}$ paracetamol, 1 $\mathrm{mg} / \mathrm{kg}$ tramadol drop, and $1 \mathrm{mg} / \mathrm{kg}$ hydroxyzine dihydrochloride were again orally administered one hour before the dressing. During the procedure, 2 NFCS points were measured and the baby never cried.

\section{DISCUSSION AND CONCLUSION}

Pain management is difficult in epidermolysis bullosa due to the variation in symptoms on any one day and

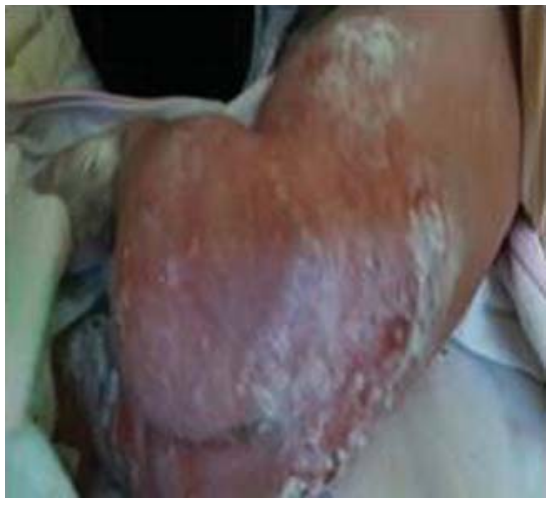

Figure 3. Appearance of lesions in patient with newborn epidermolysis bullosa 3

the multiple contributing factors (5). Pain is assessed using a recognized tool that includes behavioral and cultural characteristics (3). For newborns with $\mathrm{EB}$, mild pain generally responds to simple analgesia such as paracetamol, combined with a nonsteroidal antiinflammatory drug or nitrous oxide at home (6). Newborns with EB who have severe pain require treatment with opioid analgesia, which can be combined with an anxiolytic such as midazolam and gabapentin at home (7). The family had not accepted the use of analgesics at the first dressing in our case. However, during the application of dressings she cried very much, as such, they allowed analgesic treatment for the other dressings. We treated the patient with oral paracetamol at the 2nd wound dressing but considered that paracetamol alone was not enough because she cried constantly. For the 3rd wound dressing, we treated the patient with hydroxyzine dihydrochloride to prevent allergy during dressing, and paracetamol and tramadol for analgesia. We did not want to combine benzodiazepine and an opioid because of the risk of complications dur- 
ing home dressings. Newborns with JEB have never hand their wounds dressed at home with a combination of hydroxyzine dihydrochloride, paracetamol, and tramadol. We calculated that hydroxyzine dihydrochloride, paracetamol, and tramadol had a Ramsey sedation score of 4. In the meantime, the dressings were made comfortable. Pain, anxiety, and itching are everyday companions for these patients and an anesthetist on the EB team contributes significantly to the successful management of these problems. Implementing measures to prevent damage to the skin and mucosa, and assuming a "no-touch" approach, ensures that anesthesia for children with EB may be undertaken with few untoward consequences.

This case report highlights the important of analgesia and anesthesia for infants with EB. Children, especially newborn and infants with $\mathrm{EB}$, and some more than others, pose a formidable challenge to anesthetist. Although there is limited experience with hydroxyzine dihydrochloride during infancy, we feel that this compound should be considered when routine multimodal analgesia fails.
Where as this is a dramatic case, it details only the first few dressings and we do not know how this difficult situation for baby, parents and health care providers, continued. Although tramadol may have been useful, we do not know how this drug would help in a longer time-perspective.
Abbreviations
EB - Epidermolysis bullosa
EBS - Epidermolysis bullosa simplex
JEB - Epidermolysis bullosa junctional
DEB - Epidermolysis bullosa dystrophic form
NFCS - The Neonatal Facial Coding Scale
Conflict of Interests: The authors declare that there are no conflicts of interest related to this article.

Funding: None

\section{Licensing}

This work is licensed under a Creative Commons Attribution 4.0 International (CC BY 4.0) License.

\title{
Sažetak
}

\section{TERAPIJA BOLA TOKOM PREVIJANJA KOD NOVOROĐENČETA SA BULOZNOM EPIDERMOLIZOM: PRIKAZ SLUČAJA}

\author{
Seyhan Balli Sevgi \\ Sehit Sait Erturk Government Hospital, Ankara, Turkey
}

Epidermolysis bullosa (EB) je genetska bolest koju karakterišu plikovi po koži i mukoznim membranama kao rezultat mehaničke osetljivosti. Postoje četiri tipa EB: simplex (EBS), junkcijska (JEB), distrofična (DEB) i Kindlerov sindrom. Analgetici kao što su paracetamol ili ibuprofen kod EB su dovoljni da redukuju

\section{REFERENCES}

1. Prodinger C, Reichelt J, Bauer JW, Laimer M. Epidermolysis bullosa: Advances in research and treatment. Exp Dermatol. 2019; 28(10): 1176-89.

2. Chan JM, Weisman A, King A, Maksomski S, Shotwell $\mathrm{C}$, Bailie $\mathrm{C}$, et al. Occupational herapy for epidermolysis bullosa: clinical practice guidelines. Orphanet J Rare Dis. 2019; 14(1): 129.

3. Denyer J.Gibson E. Use of fibre dressings in children with severe epidermolysis bullosa.Br J Nurs. 2015; 24(6): S38, S40-3. bol. Opioidi i anksiolitici su potrebni kod jakih bolova tokom previjanja rana. U ovom radu je opisan slučaj JEB i terapija bola kod kuće tokom previjanja od strane anestetičara.

Ključne reči: Bulozna epidermoliza, hronični bol, pacijenti na kućnoj nezi, previjanje rane.

4. Lynne V, Burns L, Handsaker J, Murdoch JM. Epidermolysis bullosa: Management complexities of pediatric patients.B J Nurs. 2018; 27(Sup12): S20-5.

5. Togo CCG, Zidorio APC, Gonçalves VSS, Hubbard L, de Carvalho KMB, Dutra ES. Quality of life in people with epidermolysis bullosa: a systematic review.Quality of Life Research.2020; epub Apr 3.

6. Ingelmo P, Wei A, Rivera G. Nitrous oxide for procedural analgesia at home in a child with epidermolysis bullosa. Paediatr Anaesth. 2017; 27(7): 776-8.

7. Allegaert K, Naulaers G. Gabapentin as part of multimodal analgesia in a newborn with epidermolysis bullosa. Paediatr Anaesth. 2010; 20(10): 972-3.

\section{Correspondence to/Autor za korespondenciju}

Seyhan Balli Sevgi

Istasyon mahallesi, Sehit Murat Yüceler caddesi 16/15 dogu apt.

Etimesgut/ Ankara/ Turkey

email: sevgi.seyhann@gmail.com 